\title{
THE ASSASSINATION OF FUJIWARA NO TANETSUGU
}

Owing to the reuse of building materials from the Later Naniwa palace, construction on the new capital progressed swiftly - then, in the autumn of 785, Fujiwara no Tanetsugu was suddenly murdered. As we will see, three main motives apparently lay behind the murder, and although the historical records explicitly charge two families with plotting the crime, a closer look into the events reveals the involvement of two government agencies, both closely connected to Crown Prince Sawara. A detailed study of the perpetrators and their motives is necessary, as it will be used to show that the aftermath of the assassination did not affect construction efforts nor did it contribute significantly to the abandonment of Nagaoka. ${ }^{1}$

By mid-785, labourers were working day and night to construct the Nagaoka palace and capital. In the eighth month, Kanmu traveled to the Nara palace, entrusting matters of state to Crown Prince Sawara, Minister of the Right Fujiwara no ason Korekimi, and Middle Counsellor Fujiwara no Tanetsugu. In Nara, Kanmu's seven-year-old daughter, Asahara, had been preparing to assume her role as high priestess (saī or itsuki-no-miko) of the Ise shrine where in preparation for her arrival several new structures were erected. ${ }^{2}$ It was customary that before the Ise priestess left for the shrine, which took place on an auspicious day during the first ten days of the ninth month, the emperor had an audience with representatives of the Nakatomi family and handed them an imperial edict $(s e n m y \bar{o})$ informing the Ise shrine of the arrival of the new priestess. The Ise priestess was then summoned to the women's quarters of the imperial palace where the emperor himself handed her

1 Tanetsugu's assassination did, however, have major political consequences as the power of certain traditional court families decreased, eventually creating opportunities for members of new and hitherto less significant families. This will be discussed in more detail in chapter 11 .

2 SN Enryaku 4/8/24 and SN Enryaku 4/4/23. Excavations have revealed traces of expansion works to the Ise shrine during the reign of Kanmu. Tasaka and Izumi, "Koku shiseki saigū ato chōsa no saishin seika kara-shiseki tōbu no kukaku zōei puran o megutte". 
the wakare no kushi, the "comb of parting". ${ }^{3}$ Although Nagaoka was in fact the capital and imperial residence at this time, this whole ceremony took place in the Nara capital, possibly because the situation in the realm was tense and Kanmu did not want to risk incurring further opposition. Possibly he even tried to soothe his opponents by creating the impression that the Nara capital was still the 'real' capital of the state, with the Nagaoka capital as a secondary capital, as Naniwa had been previously. Another explanation could be that Kanmu went to Nara because Asahara's purification palace (saisho) was located in the vicinity of the audience hall of the Nara palace, and he wanted to avoid adding extra travel time to his daughter's journey.

When Asahara left for Ise province on the seventh day of the ninth month, several government officials accompanied her as far as the border of Yamato province. However, instead of returning to Nagaoka after seeing his daughter off, Kanmu went on a hunting trip near Mizuo hill. ${ }^{4}$ More than two weeks later, he was still absent from the Nagaoka capital.

Then, on the twenty-third day of the ninth month, around ten o'clock in the evening, Fujiwara no Tanetsugu, the head of the Construction Agency for the Nagaoka Palace, made an inspection tour to check the progress of construction activities. Suddenly, he was struck down by two arrows. The injured Tanetsugu was swiftly brought to his private residence, where he was treated. On hearing the news of the attack, Kanmu immediately returned to Nagaoka, but by the time he arrived, his trustworthy advisor had died. ${ }^{5}$

${ }^{3}$ Engi shiki, bk. 5, 127-76. A translation of the ordinances pertaining the high priestess of the Ise shrine can be found in Ellwood, "The Saigū: Princess and Priestess"; and Bock, Engi-shiki: Procedures of the Engi Era, 1: 51-6 for an introduction to the text, as well as 151-85 for a translation.

${ }^{4}$ SN Enryaku 4/9/7 and SN Enryaku 4/9/8. Many scholars assume Mizuo hill should be identified with the area of present Mizuo in Ukyō Ward, Kyoto. Takahashi Tōru, however, claims that because Mizuo is located in a remote area, it would have been impossible for Kanmu to travel from the barrier where he said goodbye to his daughter to Mizuo in just one day. Therefore he suggests that Mizuo hill might have been located in the vicinity of the Nara capital. Takahashi, Dōkyo to Nihon no kyūto, $148-49$.

${ }^{5}$ NKi Enryaku 4/9/23 and SN Enryaku 4/9/24. Although written at a much later date, a tale in the Nihon ryōiki places the murder in Shima-chō. Shima-chō might well correspond to the Shima Compound, where a winding waters party was held six months before the murder [SN Enryaku 4/3/3]. Based upon the verb used in the entry concerning the winding waters party, this compound must be located within the palace area. And, although there is no guarantee that the place name dates back to the eighth century, an area in present Kamiueno-chō, approximately 200 metres southwest of the remains of the state halls compound, was called Shimasaka until the 
Details of what happened in the aftermath of the murder have not been preserved in the Shoku Nihongi, because Kanmu himself had large parts of the passages pertaining to Tanetsugu's assassination removed ${ }^{6}$ However, more information can be found in the Nihon kiryaku. ${ }^{7}$ According to this source, the two marksmen were arrested immediately following the attack. They were identified as Hōki no Ikadamaro and Ojika no Kizumimaro. ${ }^{8}$ Then, the criminal investigation was entrusted to Controller of the Right (udaiben) Ishikawa no ason Natari. Upon interrogation, Ikadamaro soon confessed and incriminated Ōtomo no Mamaro, Ōtomo no Fūshi, Saeki no Takanari, and Ōtomo no Takeyoshi.

In total, sixteen people believed to be involved in the murder conspiracy are mentioned by name in the Nihon kiryaku, and three more can be added based on entries in the Shoku Nihongi and the Nihon sandai jitsuroku (see table 5.1). ${ }^{9}$ No less than eight of the people receiving punishment for the crime were members of the Ôtomo family. ${ }^{10}$ Traditionally, this family had served in the headquarters of the various guard units, and they continued to hold influential posts at court after the accession of Kanmu, as evidenced by Ōtomo no ason Yakamochi, Ōtomo no sukune Ojimaro, and Ōtomo no sukune Otomaro. ${ }^{11}$

beginning of the Meiji period. In the Tosa nikki, a tenth-century work written by $\mathrm{Ki}$ no Tsurayuki, reference is also made to an area called Shimasaka, located somewhere between Yamazaki and Heian. Nihon ryōiki 3, no. 38, 431-47, esp. 437, an English translation of which can be found in Nakamura, Miraculous Stories, 276-83, esp. 279; and Tosa nikki, 57.

${ }^{6}$ NKō Kōnin 1/9/10. During the reign of Heizei, these entries were once more added to the historical records, possibly at the insistence of Fujiwara no Kusuko, one of Tanetsugu's daughters. However, during the reign of Saga, after a plot involving Kusuko and her brother Fujiwara no ason Nakanari was discovered, the entries were again removed. Sakamoto, The Six National Histories of Fapan, 116-17.

${ }^{7}$ NKi Enryaku 4/9/24. A detailed analysis of the records concerning the Tanetsugu incident with a comparison between the entries in the Shoku Nihongi and the Nihon kiryaku can be found in Hayashi, Nagaokakyō no nazo, 154-60.

${ }^{8}$ Nakayama, "Mukōshi no ryakushi 32: Zōgū chōkan no ansatsu 1-Nagaokakyō (sono 15)", 3.

${ }^{9}$ Sakaehara, "Fujiwara Tanetsugu ansatsu jiken go no ninkan jinji”, 53 n. 4.

${ }^{10}$ Sakaehara Towao limits the suspects of the Ötomo family to seven. He has doubts about Minatomaro's family name. Sakaehara, "Fujiwara Tanetsugu ansatsu jiken go no ninkan jinji”, 43.

${ }^{11}$ Yakamochi had entered the select group of high court nobility as imperial advisor at the end of Kōnin's reign; one month after assuming the throne, Kanmu appointed Ojimaro, the director of the Imperial Gate Guards' Headquarters, and Otomaro, the associate director of the Left Palace Guards (saeji no suke), to the offices of director and associate director of the Consort-empress's Household Agency (chügüshiki) respectively [SN Hōki 11/2/1; SN Ten'ō 1/5/17]. 
Table 5.1 People involved in Fujiwara no Tanetsugu's assassination.

\begin{tabular}{|c|c|c|}
\hline NAME & OFFICE & PUNISHMENT \\
\hline Hōki no Ikadamaro & Inner palace guard & Put to death \\
\hline Ojika no Kizumimaro & Middle imperial guard & Put to death \\
\hline Ōtomo no Yakamochi & $\begin{array}{l}\text { Middle counsellor, director of } \\
\text { the Eastern Palace Agency } \\
(t \bar{o} g \bar{u} \text { daibu) and sword-bearing } \\
\text { general subjugating the East } \\
\text { (j̈setsu seitō shōgun) }\end{array}$ & Deprived of his rank \\
\hline Ōtomo no Naganushi & $\begin{array}{l}\text { Associate director of the Right } \\
\text { Capital Office (ukyō no suke) }\end{array}$ & Exiled to Oki province \\
\hline Ōtomo no Tsuguhito & $\begin{array}{l}\text { Assistant controller of the left } \\
\text { (sashōben) }\end{array}$ & Put to death \\
\hline Ōtomo no Takeyoshi & $\begin{array}{l}\text { Assistant executive secretary } \\
\text { of the Eastern Palace Agency }\end{array}$ & Put to death \\
\hline Ōtomo no Mamaro & $\begin{array}{l}\text { Director of the Tax Bureau } \\
\text { (shuzei no kami) }\end{array}$ & Put to death \\
\hline Ōtomo no Fūshi & $\begin{array}{l}\text { Executive secretary }\left(\text { daijo }^{\prime}\right) \text { of } \\
\text { Yamato province and assistant } \\
\text { executive secretary }(s h \bar{o} \bar{j}) \text { of the } \\
\text { Tōdaiji Construction Agency }\end{array}$ & Unclear \\
\hline Ōtomo no Minatomaro & Unclear & Put to death \\
\hline Ōtomo no Kunimichi & Unclear & Exiled to Sado province \\
\hline Hayashi no Inamaro & $\begin{array}{l}\text { Scholar in the Eastern Pal- } \\
\text { ace Agency (tōgu gakushi }) \text { and } \\
\text { vice-director of the Tōdaiji } \\
\text { Construction Agency }\end{array}$ & Exiled to Izu province \\
\hline Saeki no Takanari & $\begin{array}{l}\text { Assistant executive secretary } \\
(\text { shoshin) of the Eastern Palace } \\
\text { Agency }\end{array}$ & Put to death \\
\hline Ki no Shiromaro & $\begin{array}{l}\text { Associate director of the East- } \\
\text { ern Palace Agency (tōgū no suke) }\end{array}$ & Exiled to Oki province \\
\hline Tajihi no Hamahito & $\begin{array}{l}\text { Director of the Manuscripts } \\
\text { and Medicinals Service Bureau } \\
\text { (shushosho) of the Eastern Palace } \\
\text { Agency }\end{array}$ & Put to death \\
\hline Fujiwara no Oyori & Minister of the Treasury Ministry & Exiled to Oki province \\
\hline Prince Ioe & $\begin{array}{l}\text { Director of the Right Military } \\
\text { Guards (uhyōe no kami) and gov- } \\
\text { ernor of Echizen }\end{array}$ & Exiled to Iyo province \\
\hline Kibi no Izumi & Governor of Iyo & Demoted \\
\hline Mikuni no Hiromi & Governor of Noto & Demoted \\
\hline Sawara & Crown prince & $\begin{array}{l}\text { Deposed and exiled to } \\
\text { Awaji province }\end{array}$ \\
\hline
\end{tabular}

${ }_{12}$ According to the Nihon sandai jitsuroku, Takeyoshi was an executive secretary (daijō $)$ in one of the guards' headquarters [NSJ Jōgan 8/9/22]. 
Yakamochi, the most influential member of the Ötomo family at that time, was accused of having planned the murder conspiracy. However, he never saw the realisation of his plan, because he died less than one month before Tanetsugu was killed. ${ }^{13}$ During his long career, Yakamochi had been involved in several coups. ${ }^{14}$ The most recent affair had been the rebellion of Higami no Kawatsugu, wherein Yakamochi had played a minor role for which he was quickly pardoned and restored to his old office. Possibly owing to the influence of Crown Prince Sawara, Yakamochi was then appointed director of the Eastern Palace Agency, thereby retaining his influence. That same year, he was appointed imperial investigator (azechi) of Mutsu province, an important temporary position given only to trusted officials, and was promoted to the position of middle counsellor in 783. For the very first time a government official simultaneously served as middle counsellor and director of the Eastern Palace Agency. However, at the beginning of 784, the sixty-seven-yearold Yakamochi was appointed sword-bearing general subjugating the East. It is not quite clear whether Yakamochi actually departed for Mutsu province, but three elements support the supposition that he did. In the report Yakamochi submitted to the throne, he provided Kanmu with what seems to be an eyewitness account, but of course the report could have been written for him, and so this sole element is insufficient as proof. His biography recorded in the Kugyo bunin also reports that he was in Mutsu province when he died. ${ }^{15}$ However, the most convincing argument that he actually traveled to Mutsu province can be found in the title he received. If the prefix 'sword-bearing', a reference to the sword of office, was added to the title, it is believed these officials were in effect dispatched to their place of office.

It is interesting to note that Yakamochi was sent to Mutsu province three months before the inspection party was dispatched to look for a suitable site for the transfer of the capital. Because Yakamochi was the head of a very influential court family, Kanmu and Tanetsugu may

${ }^{13}$ SN Enryaku 4/8/28.

14 The weal and woe of the Ōtomo family and Yakamochi's involvement in coups in the second half of the eighth century are described in Cranston, A Waka Anthology, 2: The Gem-Glistening Cup, 428-29.

${ }_{15}$ For Yakamochi's career in the 780s, see SN Ten'o 1/4/14; SN Enryaku 1/6/17; SN Enryaku 2/7/19; SN Enryaku 3/2/tsuchinoto-ushi; SN Enryaku 4/4/7; and KB Enryaku 4. 
have arranged for him to be absent while they announced their plans for the move. If Yakamochi indeed went to Mutsu province, he would have left the Nara capital in the third month and would not have been expected back before the ninth month, ${ }^{16}$ giving Kanmu and his trustees enough time to plan and prepare the transfer of the capital.

Because of his presumed participation in the murder conspiracy, Yakamochi was posthumously stripped of his court rank and his remains were exiled to Oki province. ${ }^{17}$ The family property was confiscated, and Yakamochi's son Ötomo no Naganushi, was exiled to Oki province because of his presumed involvement.

Another member of the Ōtomo family punished for Tanetsugu's murder was Ōtomo no sukune Tsuguhito. In 781, Tanetsugu and Ötomo no Tsuguhito had been appointed governor and vice-governor of Ömi province respectively. Several scholars assume that conflict arose between the two men in those days. ${ }^{18}$ However, as a member of the Controllers' Office of the Left (sabenkan), Tsuguhito was charged with supervising the activities of the Ceremonies Ministry (shikibushōo), of which Tanetsugu had become minister in $783,{ }^{19}$ thereby increasing the possibility of tension arising between the two men. Although not mentioned among the accused in the Nihon kiryaku, Tsuguhito's son Ōtomo no sukune Kunimichi was also punished. ${ }^{20}$

Despite the fact that the records claim Tanetsugu's murder was a conspiracy of the Ötomo and Saeki families, some other important members of the Ōtomo family, such as Ōtomo no Otomaro and Ōtomo no sukune Kiyotari, seem not to have been involved despite serving in close quarters with some known perpetrators. Otomaro was Yakamochi's vice-general in Mutsu and Kiyotari was senior assistant minister of the

16 Murao, Kanmu tennō, 91.

17 Because the entire month surrounding the Ise priestess's journey was designated as a sacred month, certain taboos needed to be observed. Therefore, Yakamochi's remains had not been buried yet. It is also interesting to note that the verb used in the Shoku Nihongi to announce his death is 'shisu' (死), instead of the customary ' $k \bar{o} z u$ ' (薨) for gh-ranking officials.

18 SN Ten'ō 1/5/25. Murao, Kanmu tennō, 111; Nakayama, "Zōei jigyō no tenkai", 321; and Fukuyama et al., Nagaokakyō hakkutsu (shimpan), 52. Murao Jirō suggests that instead of travelling to Ōmi province, Governor Tanetsugu spent most of his time in the capital, leaving the administration of the provincial headquarters in the hands of his vice-governor, Tsuguhito.

19 SN Enryaku 2/7/25.

${ }_{20}$ Kunimichi's involvement in the Tanetsugu incident is testified to by an entry in the Nihon sandai jitsuroku dated 866 [NSJJōgan 8/9/22]. The Kugyo bunin also states that Kunimichi was exiled because of his father's part in the murder [KB Kōnin 14]. 
Military Affairs Ministry. Moreover, as middle captain of the Inner Palace Guards, Kiyotari was also Hōki no Ikadamaro's supervisor. If in fact the whole Ötomo family was involved in the conspiracy, it seems likely that these two men were involved and also punished.

The same goes for the Saeki family, descendants of a side branch of the Ötomo family. According to the preserved records, only one member of this family, Saeki no Takanari, a low-ranking bureaucrat in the Eastern Palace Agency, was punished. If it really was a conspiracy involving the two families, Saeki no sukune Mamori and Saeki no sukune Fukutori, both colleagues of Hayashi no Inamaro and Ōtomo no Fūshi in the Tōdaiji Construction Agency, must also have been involved. Also, a mere five days after the murder, another member of the Saeki family, Saeki no Katsuragi, was appointed assistant controller of the left, a position that had become vacant after the execution of Ōtomo no Tsuguhito. ${ }^{21}$ Again, if the entire Saeki family was indeed involved, it is highly unlikely Kanmu would have appointed one of its members to a central government position.

The interrogations also revealed the name of Northern House Fujiwara no ason Oyori. Tsunoda Bun'ei has suggested that Fujiwara no Oyori became involved in the plot because of his marriage to a daughter of Otomo no Kiyotari, ${ }^{22}$ but since there is no proof that even Ôtomo no Kiyotari himself was involved, this explanation is unconvincing. It is possible that Oyori felt resentful about the implicit confidence Kanmu extended to Tanetsugu. ${ }^{23}$ Oyori might have felt

21 SN Enryaku 4/9/29.

22 Tsunoda, "Kanmu tennō", 49.

23 Kanmu's reliance on Tanetsugu and Tanetsugu's supposedly swift rise up the bureaucratic ladder during the early Enryaku era are often attributed to Tanetsugu's position as the nephew of Fujiwara no Momokawa. When Momokawa died in 779, his son Otsugu was only five years old, and Momokawa's sole surviving brother, Tamaro, was already fifty-seven years old. Therefore, Tanetsugu stepped in as Momokawa's successor. But this hardly seems sufficient as an explanation. Takahashi Tōru has suggested that, since Kanmu and Tanetsugu were maternally related to the descendants of Korean immigrants, both men had a similar upbringing and outlook. Takahashi suggests that both men were greatly influenced by Taoism, and that this, in addition to their being of the same age, contributed to a deep friendship between the two men. Takahashi, Dōkyō to Nihon no kyūto, 194-95. Although Tanetsugu might have been one of Kanmu's closest advisors, that privilege was not extended to his children. In 787, Yumori, one of Tanetsugu's sons, received the family name and hereditary title of Ite no sukune after previously having been removed from the family register (koseki) for an unknown crime [NS Enryaku 6/9/27]. Kanmu also removed from office Tanetsugu's daughter Fujiwara no ason Kusuko, who was serving in the Eastern Palace Agency $(t \bar{o} g \bar{u} b \bar{o})$ of Crown Prince Ate [NKō Kōnin 1/9/10]. 
that as the son of Fujiwara no Nagate and a daughter of Fujiwara no Yoshitsugu, two high-ranking court officials of the previous decade, he was more important than Tanetsugu, the son of an insignificant member of the Ceremonial Fujiwara and the daughter of a Paekche descendant. Moreover, Oyori's mother was a sister of Fujiwara no Otomuro, Kanmu's consort-empress. Oyori might therefore have been envious of Tanetsugu's rise up the bureaucratic ladder once Kanmu was enthroned. ${ }^{24}$ Although Tanetsugu's rise up the bureaucratic ladder was not that unusual when compared to the progress of other government officials of influential court families, in 782 he was but a low member of the high court nobles $(k u g y \bar{o})$, ranking ninth of eleven imperial advisors. ${ }^{25}$ However, with his appointment as middle counsellor two years later, he surpassed several long-time imperial advisors, among them Ôtomo no Yakamochi, and this promotion may have caused envy among the other court nobles.

One of Kanmu's nephews, Prince Ioe, was also involved in the conspiracy. ${ }^{26}$ It is difficult to understand why he wanted to eliminate Tanetsugu, but since he was closer in age to Sawara than to Kanmu, it is generally believed that he had a closer affinity to the former. ${ }^{27}$ Because the entry in the Nihon kiryaku states that Ioe should have been executed but that his punishment was lessened to exile due to his high birth, Ioe's role in the whole conspiracy must have been deemed significant.

${ }^{24}$ During the reign of Kōnin, Oyori was always ranked two grades higher than Tanetsugu, but in the final month of 780 and the first month of 781, Tanetsugu received two promotions, effectively placing both men at the same level [SN Hōki 11/12/11; SN Ten'o 1/1/16]. A few months later, Oyori and Tanetsugu were both promoted to the junior fourth rank upper grade [SN Ten'o 1/4/15]. Over the next three years, Tanetsugu received three promotions in rank as he also received increasingly higher responsibilities. In 782, he became imperial advisor, and in 784 he was appointed middle counsellor [SN Enryaku 1/3/26; SN Enryaku 3/1/16]. During this time, Tanetsugu was also appointed head of the construction agency of the Nagaoka capital and ceremonies minister (shikibu no kami), while Oyori became treasury minister (ōkura no kami) but did not receive his next promotion in court rank until one month before Tanetsugu's death [SN Enryaku 4/5/20; SN Enryaku 4/8/7].

${ }^{25} \mathrm{~KB}$ Ten'ō 2.

${ }^{26} \mathrm{SN}$ Enryaku 1/6/21. Ioe was the son of Noto, Kanmu's full sister, and Prince Ichihara.

${ }^{27}$ Nakayama, "Zōei jigyō no tenkai", 322. Ioe's father Ichihara also seems to have had a very close relationship with Yakamochi. See Yamanaka, "'Tōgū' meibokushodoki to Nagaokakyū no tōgūbo - Nagaokakyū ato dai 128ji (7AN10K chiku) chōsa ryakuhō", 11 . 
Two more names of government officials must be mentioned in connection with the Tanetsugu incident. Two weeks after the murder, Kibi no ason Izumi was demoted to the office of acting governor (gon no kami) of Sado province. Although no explanation is given for why he was demoted, the general consensus is that it was because of his involvement in Tanetsugu's assassination..$^{28}$ The murder and the severe punishment Izumi received are too close together in time to suppose anything else. Supporting this view is an entry in the Nihon kōki dating from 804, which states that Izumi's crimes were pardoned together with those of Ioe and Fujiwara no Oyori, two known conspirators. ${ }^{29}$ The second government official who deserves attention is Mikuni no mahito Hiromi, governor of Noto province at the time of the murder. He was exiled to Sado province for reasons that might be connected to the assassination of Tanetsugu. ${ }^{30}$

Finally, during the interrogations, the name of Kanmu's younger brother Sawara was also mentioned. He is reported to have given the plot full support. As a result, guards were sent to the Eastern Palace (tōg $\bar{u}$ or haru no miya) on the evening of the twenty-eighth day of the ninth month, four days after Tanetsugu's death. Sawara was stripped of his title as crown prince and held captive in the Otokunidera. Indignant about the accusations, he started a hunger strike, but Kanmu did not relent, and several days later he dispatched Imperial Household Minister Ishikawa no Kakimori to accompany Sawara to his place of exile on Awaji Island. The weakened former crown prince did not reach his destination alive. He died near Takase bridge, a bridge across the Yodo River at a short distance from the Nagaoka capital. Refusing to grant leniency to the deceased former crown prince, Kanmu nonetheless insisted that his remains be brought to Awaji, where they were interred.

\footnotetext{
${ }^{28}$ SN Enryaku 4/10/2. Saeki, "Kanmu tennō no kyōgai”, 239. Bruno Lewin assumes the demotion was connected to an incident for which Izumi had already been punished early in 784 [SN Enryaku 3/3/25]. Lewin, "Die Regierungs-annalen Kammu-Tenno", 133, 179 n. 249.

${ }^{29}$ NKō Enryaku 24/3/20. At that time, Kanmu was gravely ill. In an attempt to cure his illness, various Buddhist ceremonies were ordered, monks and government officials were bestowed with honours and gifts, various attempts were made to placate Sawara's spirit, and several people involved in coups during Kanmu's reign were pardoned. For more details about Kanmu's final months, see chapter 13.

${ }^{30}$ SN Enryaku 4/11/8.
} 
It is often said that Tanetsugu's murder was part of a much wider conspiracy against Kanmu that came about because Sawara wanted to rule himself. ${ }^{31}$ However, it is hard to accept that Sawara would have risked his chances of accession by murdering his brother's closest advisor without making sure that Kanmu himself would be eliminated at the same time. Whether Sawara was really the instigator of Tanetsugu's murder is not clear. At any rate, there was a close connection between the crown prince and most of the known perpetrators, and he also seems to have had a motive.

First of all, at least six of the plotters were attached to the Eastern Palace Agency, the government office responsible for all matters regarding the heir apparent. In addition to Ôtomo no Yakamochi, Saeki no Takanari, and Ōtomo no Takeyoshi, Tajihi no Hamahito, Ki no Shiromaro, and Hayashi no Inamaro, were also involved. Interestingly, the last two men also provide us with a connection to the Tōdaiji Construction Agency. Inamaro was the construction agency's vice-director, a position Shiromaro had held near the end of Konnin's reign. ${ }^{32}$ Sawara himself also had had close dealings with the Tōdaiji and its construction agency during the 760s and 770s. It thus seems likely that even after he returned to secular life upon his appointment as crown prince, he still had significant influence - and friends - in both the temple and the construction agency. ${ }^{33}$

As for motive, the medieval Mizu kagami contains a story that might point to tension between Sawara and Tanetsugu. ${ }^{34}$ According to this story, Sawara had appointed Saeki no Imaemishi imperial advisor during one of Kanmu's absences from the capital. Tanetsugu strongly protested this appointment, for it was unprecedented that a member of the Saeki family achieved such a high position. Upon Kanmu's return, the appointment was annulled, and in return Imaemishi received a promotion in rank. The whole story, however, seems doubtful. It is set in 782, the year in which Imaemishi indeed rose to the junior third rank, according to the official histories. ${ }^{35}$ However, judging from the

31 Fukuyama et al., Nagaokakyō hakkutsu (shimpan), 54.

32 SN Hōki 10/11/28.

33 As a matter of fact, a document in the Tódaïi yōroku refers to the continued support of Sawara's Eastern Palace Agency for the temple. Tödä̈i yōroku, bk. 7, 267. For a detailed discussion on the connection between Sawara and the Tōdaiji, see Hongo, "Kōnin Kanmu chō no kokka to bukkyō: Sawara shinnō to Daianji Tōdaiji".

${ }_{34}$ Mizu kagami, 91.

35 SN Enryaku 1/6/21. 
offices and ranks Kanmu would bestow upon him during the next three years, his service seems to have been greatly appreciated. ${ }^{36}$ Moreover, at the end of 784, when Tanetsugu was still alive, Imaemishi was indeed appointed to the office of imperial advisor. ${ }^{37}$ It seems unlikely that less than two years after the incident Tanetsugu would no longer object to the precedent of seeing a Saeki appointed to high office, or that Kanmu would have changed his mind and ignored his trusted advisor's objections.

Therefore, other events may have caused the tension between Sawara and Tanetsugu. As the ceremonies minister, Tanetsugu had been responsible for the selection of government officials from mid-783. Four months prior to that, Sawara's preceptor (tōguf $f u$ Fujiwara no Tamaro had died, and he seems not to have been replaced. ${ }^{38}$ When Ötomo no Yakamochi was appointed one year later as sword-bearing general subjugating the East, another high-ranking official in the Eastern Palace Agency disappeared from the scene. It is doubtful that Tanetsugu would have had the power to single-handedly take these decisions, but the lack of a preceptor and director might have caused ill feelings between Sawara and Tanetsugu.

Sawara may also have felt that his own position as crown prince was endangered by Tanetsugu's family connection with Kanmu's principal consort. Tanetsugu may in fact have been looking for an opportunity to depose Sawara and establish Kanmu's son Ate, who was born from a Ceremonial House Fujiwara woman, in his place. ${ }^{39}$ This action might even have had the full support of Kanmu. After all, he was raised in the family of his mother, descendants of immigrants from Paekche, where patrilineal succession by the eldest son was preferred. ${ }^{40}$

\footnotetext{
${ }^{36} \mathrm{He}$ was appointed master of the Consort-empress's Palace, was a member of the Nagaoka Palace Construction Agency, and rose to the senior third rank [SN Enryaku 4/6/18]. After the incident, Imaemishi replaced Tanetsugu as head of the construction agency, albeit for just seven months. Murao Jirō suggests that the author of the Mizu kagami had Imaemishi confused with a member of the Ōtomo family. Tsunoda Bun'ei on the other hand supposes that a reversal in names between Sawara and Tanetsugu occurred while compiling the Mizu kagami. Murao, Kanmu tennō, 89; and Tsunoda, "Kanmu tennō", 52.

37 SN Enryaku 3/12/2.

${ }^{38}$ SN Enryaku 2/3/19.

${ }^{39}$ Originally, his personal name was Ote, but in 783 this name was changed into Ate [SN Enryaku 2/4/14]. In the historical records, Ate is considered to be Kanmu's eldest son. However, when he was born, his father was already thirty-eight years old. It is therefore likely that Kanmu had older children.

${ }^{40}$ Piggott, The Emergence of Fapanese Kingship, 123.
} 
Furthermore, Sawara had been appointed crown prince at the request of the retired Emperor Kōnin, but Kanmu may have found his brother too involved in Buddhism, since Sawara had not returned to secular life until his selection as crown prince. ${ }^{41}$ He may have feared another reign during which Nara Buddhism was excessively promoted and again involved in politics. Kanmu could have tried to make an agreement with Sawara stipulating that Sawara would pass the throne to Ate, but as the events resulting in the Jinshin War of 672 had undoubtedly taught him, after his death he could no longer control the situation. So, even if Sawara was not directly involved in the murder, Kanmu might have seized the occasion to get rid of his brother and assure succession by his own son.

Finally, with Sawara's strong connections to Nara Buddhism in general and the Tōdaiji in particular, it seems highly unlikely that the crown prince would have favoured a relocation of the capital. This may also have put him in conflict with Tanetsugu.

Thus there seem to have been three main motives behind the murder. First of all, there seems to have been a strong opposition against the rise of the Ceremonial House of the Fujiwara family, and of the rise of Tanetsugu in particular. Certain members of the Ötomo, the Saeki, and the Northern Branch of the Fujiwara family felt excluded from power at court by somebody who was not even a direct descendant of Fujiwara no Momokawa. Second, the murder was an expression of resentment by these powerful people against the move of the capital from Nara, their stronghold, to Nagaoka. And finally, there seems to have been some cause for conflict between Sawara and Tanetsugu. ${ }^{42}$

In the months following the deaths, executions, and banishments, the Shoku Nihongi abounds with entries referring to appointments and promotions. ${ }^{43}$ These were all aimed at achieving tighter control over the court officials by Kanmu. Several of those appointed were the Emperor's relatives or people of immigrant kinship groups. Kanmu was thus building a close-knit circle of trusty followers at court. ${ }^{44}$

\footnotetext{
27.

${ }^{41}$ Takinami, Heian kento, 30; Hongō, "Kōnin Kanmu chō no kokka to bukkyō",

${ }^{42}$ These three reasons are also listed by William McCullough in "The Heian Court", 24.

${ }^{43}$ For more detailed research on this topic, see Sakaehara, "Fujiwara Tanetsugu ansatsu jiken go no ninkan jinji”.

${ }^{44}$ For further details, see chapter 11.
} 
A new heir apparent was quickly selected. Ate, Kanmu's eleven-yearold son with Consort-empress Otomuro of the Ceremonial Branch of the Fujiwara family, was made the new crown prince. The staff of Ate's Eastern Palace Agency was also immediately appointed. Fujiwara no Tsugutada, who had close ties to the Kudara no konikishi family, became Ate's preceptor; while Asahara no imiki Michinaga and Tsu no muraji Mamichi, both members of immigrant kinship goups, filled the positions of the two scholars of the Eastern Palace Agency. Ki no Kosami, a paternal relative of Kanmu, and Abe no ason Hirotsumaro were appointed director and associate director of the Eastern Palace Agency respectively. ${ }^{45}$

In the Council of State, Ishikawa no Natari and Ki no Funamori took up the offices of middle counsellor that had become vacant after the deaths of Tanetsugu and Yakamochi. Ki no Kosami filled the vacancy of imperial advisor left after Fujiwara no Ieyori's demotion. Sakanoue no Karitamaro took up Ioe's post as governor of Echizen; and the same day, Ishikawa no ason Kimitari was appointed to the position of the executed Ōtomo no Mamaro, while the post Kimitari previously held - director of the Statistics Bureau (shukei no kami) — was given to Hata no Tarinaga. ${ }^{46}$

Imaemishi replaced Tanetsugu as the head of the agency for the construction of the Nagaoka palace. However, seven months later he was demoted to the office of governor-general of the Dazai Headquarters (dazai no sotsu) and was exiled to Kyūshū ${ }^{47}$ It is not clear why Imaemishi was demoted, but as a long-time member of the Tōdaiji Construction Agency he, too, might have been too close to the faction in favour of Sawara. Because Imaemishi also held the offices of master of the Consort-empress's Palace (kōgōgu daibu), popular affairs minister and governor of Yamato at the time of his exile, replacements were once more in order. Crown Prince Ate's preceptor Tsugutada became popular affairs minister and Ōnakatomi no ason Tsugimaro was appointed governor of Yamato. The following month, Tsugutada was given even more responsibilities when he was also appointed director of the Tōdaiji

\footnotetext{
45 SN Enryaku 4/11/25.

46 SN Enryaku 4/11/25; SN Enryaku 4/10/12; and SN Enryaku 4/10/12.

47 SN Enryaku 5/4/11.
} 
Construction Agency. ${ }^{48}$ With Tsugutada in charge of construction and the monk Tōjō as the temple's chief administrator, Kanmu was now in firm control of the Tōdaiji.

In the end, the assassination of Tanetsugu and the many personnel changes after his death did not significantly affect construction on the Nagaoka capital. On the contrary, soon a new construction phase started demonstrating Kanmu's resolve to make a success out of his newly established capital.

${ }^{48}$ SN Enryaku 5/4/11; SN Enryaku 5/4/19; and SN Enryaku 5/6/9. Further information on the staffing of the Tòdaiji Construction Agency after Tanetsugu's death can be found in Hayashi, "Zō-Tōdaiji-shi no haishi o megutte", 231-33. 